\title{
QUALITY LIBRARY INFORMATION RESOURCES AND POSTGRADUATE STUDENTS' SATISFACTION IN IGNATIUS AJURU UNIVERSITY OF EDUCATION LIBRARY
}

\section{Emmanuel Okwu (Ph.D) ${ }^{1}$ and Dorathy Braide ${ }^{2}$}

${ }^{1}$ Department of Library and Information Science, Faculty of Education, Ignatius Ajuru

University of Education. Rumuolumeni, Port Harcourt, Nigeria

${ }^{2}$ Ignatius Ajuru University of Education. Rumuolumeni, Port Harcourt, Nigeria.

Cite this article:

Emmanuel O., Dorathy B. (2021), Quality Library Information Resources and Postgraduate Students' Satisfaction in Ignatius Ajuru University of Education Library. British Journal of Library and Information Management 1(1), 25-38. DOI: 10.52589/BJLIMJEFLRTXJ.

\section{Manuscript History}

Received: 11 June 2021

Accepted: 9 July 2021

Published: 20 July 2021

Copyright $\odot 2020$ The Author(s). This is an Open Access article distributed under the terms of Creative Commons AttributionNonCommercial-NoDerivatives 4.0 International (CC BY-NC-ND 4.0 ), which permits anyone to share, use, reproduce and redistribute in any medium, provided the original author and source are credited.
ABSTRACT: The study sought to determine the quality library information resources and postgraduate students' satisfaction in Ignatius Ajuru University of Education library. Two research objectives, two research questions and two hypothesis were formulated to guide the study. Descriptive survey research design was adopted for the study. The total population of the study was 412 postgraduate students' registered with Ignatius Ajuru University of Education Library while the sample size was 206 postgraduate students' selected using simple random sampling technique. The study found that that there is a significant relationship between available information resources and postgraduate students' satisfaction with the use of Ignatius Ajuru University of Education library F1, 200=4.730, p<.05. Therefore, the null hypothesis one was rejected at 0.05 alpha level. The study recommended that Relevant information resources to the library users' field, accessibility, adequacy, clarity of language of presentation, authenticity of information resources regular power supply, adequate computers/internet facilities should be considered and made available for the library users; also, Awareness services should be done on regular basis in order to increase users' knowledge on library usage in order to guarantee users' satisfaction of Ignatius Ajuru University of Education library.

KEYWORDS: Quality Library Information Resources and Postgraduate Students' Satisfaction in Ignatius Ajuru University of Education Library 


\section{INTRODUCTION}

\section{Background of the study}

The role of university libraries in the new knowledge boom arising from the impact of Information and Communication Technologies (ICT), which have continuously eased the way we access and use information, is supported by reliable evidence in scholarly works (Nnadozie \& Nwosu 2016; Rasul \& Singh 2017). According to Kim-Soon and Ahmad (2013), the aim of facilities in a library is to ensure that users have access to valuable information tools and services. They argue that the library cannot fulfil its mission if the tools and facilities it offers do not meet the demands of its users. Although the Ignatius Ajuru University of Education (IAUE) Library has expanded its collections and strengthened its infrastructural and human capital in line with the primary goal of a modern academic library, satisfaction is not always guaranteed. The aim of this study was to determine the extent to which postgraduate students were satisfied with the quality of information resources available at the Ignatius Ajuru University of Education Library.

Evaluating information resources is not a new concept. There is ample evidence that students including the present crop of postgraduate students, born in the era of Information and Communication Technology (ICT), often described as a digital generation should have acquired the capacity to know how to and where to go to evaluate different information resources at their disposal. There is a grand consensus among all walks of academia that with the infinite variety and levels of scholarship available today, the evaluation of information resources is one of the most important skills that every student and scholars should possess, which of course librarians and instructors, have been teaching students (Wichowski \& Kohl, 2013; Blakeslee, 2004). One of the most popular criteria available for evaluating information resources is that developed in 1998 by a librarian named Jim Kapourn, which is an evaluation checklist to help students determine if a website was credible. The checklist has 5 criteria; accuracy, authority, objectivity, currency, and coverage (AAOCC). Many scholars have modified these criteria, in particular, the "CRAAP" created by Blakeslee (2004) of Meriam Library, one of the University of California libraries. Essentially, it is meant to help students evaluate the information resources for Currency, Relevance, Authority, Accuracy, and Purpose, thus the acronym CRAAP.

The academic libraries are established essentially as the custodian of information resources by procuring information materials and providing other services that support the teaching, learning and research activities of their parent institutions.

Academic library collections that were previously based upon the collection of physical library materials such as paper formats have now gone digital (Akpojotor 2016; Mohammed, Alhassan and Oyedum 2018). Some describe academic libraries today as dynamic and complex institutions with multiple roles and a host of related operations and services developed over the years whose primary objective has remained to provide access to trustworthy, authoritative knowledge (Nnadozie and Nwosu, 2016). The rapid growth in the number of information resources both in traditional print and the burgeoning electronic media resources are increasing the necessity for more quality assurance in the information people seek from the library information retrieval systems. 
By its nature, as a center of excellence, universities are more likely to be explicitly concerned with information quality than other populations. Characteristically, a postgraduate work is heavily involved in an interaction with information: Postgraduate students find relevant information, assess the quality of the information, and use information in their research process. However, the competence of these students in evaluating the quality of information or seeking and using quality information for learning and research related activities is not certain. It depends among other things; their knowledge of the services provided by the academic library, the information resources available in the library, how accessible are these information resources, and what is the difference in the quality of information resources obtainable in the library compared to other sources. Without critical evaluation, using the time-tested library information retrieval systems one could easily pass information from Google or other sources as just the same with academic library sources. On the other hand, Rieh and Belkin (1998) reported that most scholars feel competent to judge quality and authority based on their evaluation criteria in the printed environment with which they are familiar with in their scholarly publications.

Some writers report that the students typically begin their information seeking processes with search engines which require less expertise than those of more authoritative sources such as traditional and online library information retrieval systems (Son 2013; Taylor 2012; Campbell 2006).

Users' satisfaction is the level at which services rendered to users meet their expectations and pleasures. User satisfaction is an evaluation of a product or service in terms of whether that product or service has met their needs and expectations (Motiang, Wallis and Karodia, 2014; in Bala, Abubakar, and Usman, n.d.). Satisfaction with the resources and services of a library portrays the information resources and services of good quality and worthy of use.

It is in the opinion of some library and information science scholars that a comprehensive understanding of the information seeking behaviour of the postgraduate students can help reshape their information environment (Holliday and Li, 2004) and to better assist them with their information needs in the context of learning (Son 2013). This study therefore aligned with how the quality of information resources in Ignatius Ajuru University of Education library satisfies the information needs of the postgraduate students of the institution.

\section{Statement of the Problem}

A university library is a library connected to a university that supports the university's teaching, studying, and academic activities. To do this, the university library is required to include a wide range of information services in any format. Since postgraduate students are the library's most frequent users, the library's facilities and programmes should be designed with them in mind. This is due to the fact that postgraduate students' study is geared toward science.

They can also come across a wide range of information sources of varying consistency. To achieve a high-quality result, as needed for postgraduate level work, all sources are typically thoroughly analysed before depending on their data. Given that all secondary evidence is created for various reasons, references must first be assessed for their importance to the project. The sources are then evaluated for their currency, authority, accuracy, and intent after they seem to be significant. As a result, postgraduate students need high-quality information resources to fulfil their learning goals, and libraries are required to offer this assistance. 
However, whether libraries are stocked with quality information resources to the satisfaction of postgraduate students is unknown to the researcher. Non-currency, non-relevance, poorauthority, inaccuracy, and their purpose not met could hamper postgraduate students' academic achievement which could also lead to inadequate use of information resources by the postgraduate students. It is against this backdrop that the study sought to determine the quality library information resources and postgraduate students' satisfaction in Ignatius Ajuru University of Education Library.

\section{Objectives of the Study}

The main purpose of this study is to examine quality library information resources and postgraduate students' satisfaction in Ignatius Ajuru University of Education Library. The specific objectives of the study are as follows:

1. To determine the relationship between the print information resources and postgraduate students' satisfaction in Ignatius Ajuru University of Education library.

2. To ascertain the relationship between the electronic information resources and postgraduate students' satisfaction in Ignatius Ajuru University of Education library.

\section{Research Questions}

The following research questions will guide the study:

1. What is the relationship between print information resources and postgraduate students' satisfaction in Ignatius Ajuru University of Education library?

2. What is the relationship between electronic information resources and postgraduate students' satisfaction in Ignatius Ajuru University of Education library?

\section{Hypothesis}

The following hypotheses was tested at 0.05 level of significance:

HO1: There is no significant relationship between print information resources and postgraduate students' satisfaction in Ignatius Ajuru University of Education library.

HO2: There is no significant relationship between electronic information resources and postgraduate students' satisfaction in Ignatius Ajuru University of Education library.

\section{Significance of the Study}

The researcher hopes that the findings will be of immense benefit to the society considering that university library plays an important role as the primary providers of quality information resources to the satisfaction of the academic community. The increasing demand for postgraduate studies and growing field of studies undertaken by the Ignatius Ajuru University of Education justifies the need for evaluation of how university libraries warehouse information but also in how users perceive the quality of information resources provided by libraries. A richer and more coherent understanding of postgraduate students' use of various library information resources as hoped to be revealed in the study will help reshape the information environment for the postgraduates to assist them better with their information needs in the context of quality of information resources. 
The study may also, through the recommendations to be made, assist the Department of Library and Information Science, researchers, lecturers and postgraduate students.

The researcher also hopes the study will help uncover the critical areas in the educational process that many researchers were not able to explore. The study will enhance a better understanding of the interplay between quality of information resources in the possession of the library and the postgraduate students' satisfaction with the use of the library.

\section{CONCEPTUAL REVIEW}

\section{Information}

The concept "information" is fundamental to all the information disciplines, perhaps this is why it has been defined in countless ways, across many disciplines over many decades. Several attempts have been made by different researchers to define information in a conceptually sound way. Information can then be described as what postgraduate students employ, require and seek to accomplish their work, for their research, education, recreation, socio-economic life, etc.

Besides, the university and institutions require information to enable them to provide the necessary support in the design of information and support resources provided to postgraduate students. The inadequacy of information and services for postgraduate study is what Abiddin and Ismail (2011) conclude impinge on the attrition and completion rates of postgraduate studies.

\section{Information needs}

According to Talja in Anwar \& Asghar (2016), "information needs arise when an individual finds himself in a problem situation when he or she no longer can manage with the knowledge that he or she possesses". They contend that it is the information need that activates information seeking which is initiated by "uncertainty due to what Kuhlthau (1993) described as lack of understanding, the gap in meaning, or a limited construct".

Postgraduate students have an inherent information need or gap which inform the reason they engage in different information seeking behaviour to bridge this gap, this is in line with Wilson's 1997 information seeking behaviour model where it noted that information needs are influenced by background, characteristics such as emotional, educational, demographic, social or interpersonal, environmental, and economic intervening variables; and by social context in which the need arises (Wilson, 1997). Satisfying information needs is a dynamic process that the outcome may lead to renewed information needs (Kuhlthau, 1991).

\section{Information seeking}

In the views of Kundu (2017) "any analysis of the literature of information-seeking behaviour must be based upon some information behavior models, of which information seeking and information-seeking behaviour are two parts". According to Kundu, information behaviour is meant by the activities of a person that may be engaged in identifying their own needs for information, searching for such information in any way, and using or transferring that information. As pointed out by Pettigrew, Fidel \& Bruce cited in Son, (2013), individuals basically "need, seek, give, and use information in different contexts". Different areas of 
information seeking behavior have been the focus of many studies including information need initiation, information gathering, as well as information sharing and use in distinct disciplines or contexts (Son 2013).

\section{Information seeking behaviour of Postgraduate Students}

To understand the information seeking behaviour of postgraduate students it is important we put in perspective various issues that relate to the student and the interplay of the environment in which the postgraduate students operate. They include cultural background, personality issues, educational, demographic, social or interpersonal context, environmental concerns, and economic matters. In particular, Abiddin and Ismail 2011, describe postgraduate studies as a growth process where students, have to develop as scholars with the support and guidance of the institution. Postgraduate students are matured persons, pursuing an academic career path after their Bachelor Degree or Higher Education, and they represent a significant range of diversity: age; cultures; capability; nature of the program (part-time, full-time, internal or external); their changing needs over time/place/space.

\section{Information Resources}

referred to as information resources. In the works of Iwhiwhu and Okorodudu (2012) on the evaluation of user satisfaction of Public Library Information Resources, Facilities, and Services, they explain that in a library and information science research, information can be perceived as a product that can only be consumed together with delivery systems and/or services. Information resources are one of the significant processes of communication. Many observers believe information resources does not only facilitate communication of information but also made possible the transmission, storage, preservation and future use of the information. It is also considered as an assemblage of valued information generated through human activities.

\section{Users' Satisfaction}

The fundamental role of libraries is information dissemination to meet the information needs of its users. Foremost among its role is the provision of the desired information resources, facilities, and services expected by its users. Library in the views of library and information science scholars exist to satisfy its users. This implies that users' satisfaction refers to how users weigh the services of libraries. As mentioned earlier, library's role is to fulfill the information needs of its user, which Iwhiwhu and Okorodudu (2012) admit that it is only the user that can tell if the library meets his expectation. Ogunsola, cited in Iwhiwhu and Okorodudu, agrees that satisfying users is a major concern and an integral part of library and information science practice.

\section{University Library Information Resources}

University Libraries collect and preserve diverse information resources for the benefit of its users, which are mainly encyclopedias, books, newspapers, journals, and other editorials, but with the advent of the internet, digital sources of information have become prevalent. These digital sources of information include, but not limited to, online libraries and journals, online encyclopedias like Wikipedia, blogs, video logs like YouTube, etc. Even movie clippings, especially from history, have played a large role in modern research, and hence are classifiable under 'Library Resources'. 
The availability of information resources entails carefully selecting, acquiring and also providing means by which postgraduate students could get the necessary information resources needed. Oriogu (2015) agree that 'information resources availability is a function of their presence in the libraries. Adeleke (2005) contended that libraries should procure resources and guarantee viable use of such resources by their clients to enable them to add to the headway of information. Without the availability of information resources, accessibility will be difficult and its utilization impaired.

\section{Empirical Review}

A couple of empirical studies have been carried out on the quality of information and users' satisfaction and use of library within and outside Nigeria. Some of the reviewed studies which are relevant to this study are discussed as follows:

Mohammed, Alhassan and Oyedum (2018) studied the impact of quality information resources on students' academic performance in tertiary institutions in Niger State, Nigeria. The objectives of the study were to ascertain the availability of information resources, establish the impact of the quality of information resources on students' academic performance among others. The findings from the study revealed that most of the information resources were not available in the academic libraries and that the quality of information resources and its utilization has a positive impact on the academic performance of undergraduate students. This revealed that the quality of information resources affects students' academic performance in tertiary institutions in Niger State.

In a similar study conducted by Bala, Abubakar and Usman (n.d.) that examined the influence of Quality of Information Resources on Tertiary Students' Satisfaction in Academic Libraries in Niger State, Nigeria. The study showed that the available information resources in the libraries possess such considerable qualities as relevance, accessibility, adequacy, authenticity, good authority and clarity and have to a very great extent satisfied users' information needs. Inadequate reading chairs and tables, rampant power outage, poor ventilation and lighting, lack of awareness on the arrival of new library materials, improper user education, etc. were identified as inhibiting factors to the effective utilization of information resources and users satisfaction in academic libraries in Niger State.

Nnadozie and Nwosu (2016) undertake an examination of user satisfaction amongst final year students in four federal university libraries in the South-East Zone of Nigeria. The findings revealed that graduating students are satisfied with the traditional library resources, reference services, photocopying services, as well as ergonomic-related facilities provided by libraries in their respective institutions. However, the majority of these students expressed disappointment with the level of access to computers and other ICTs, irregular internet services, outdated textbooks, among others.

In the same vein, Kim-Soon, Hasbi, and Ahmad (2013) studied user satisfaction on the library information resources, facilities, and services of a public university. The study reveals the quality consciousness regarding the online information resources among the library users who use the Internet. With this awareness, the University libraries are improving on their facilities to provide satisfaction in accessing and studying information to meet today's knowledgeintensive environment. The result of this study reflected the needs of good library information resources, facilities, and services to ensure user's satisfaction for learning and research 
Saikia and Gohain, (2013) carried out a study titled Use and user's satisfaction in library resources and services: A study in Tezpur University (India) This study which employed the survey research design sought to find out the use of library resources, user's satisfaction with library resources and services and information seeking behaviors of the students and research scholars of Tezpur University. 79.5\% (159) library users responded where $32.07 \%$ (51) respondents visited Central library, Tezpur University every day for borrowing library books. It is found that $82.39 \%$ (131) users borrowed text books, (79.87\%) (127) consulted journals and $75.47 \%$ (120) read newspapers to meet their information needs. The library is playing a vital role to meet multidimensional demands of students, and research scholar for information and knowledge. The study conclude that user guidance is a necessity that is required to help library users to meet their information needs as well as make users mindful of the available library resources and services.

Singh and Kuri (2017) studied Users' Satisfaction with Library Resources and Services: A Case Study of the Indian Institute of Technology (IIT) Libraries in India. The study which is a survey research looked at Users' Satisfaction with Library Resources and Services in IIT Libraries in India. The findings revealed that users' satisfaction with library resources differed according to the level of study of the respondents and some suggestions were included in the study to increase users' satisfaction in libraries.

Several studies revealed that users' satisfaction is a function of the quality of staff and services of a library. This view was supported from the survey conducted by Adeniran (2011) which implies that user-satisfaction with services in libraries which are well-stocked and the materials properly arranged and manned by well-qualified experienced staff would be significantly higher than user satisfaction with libraries with less qualified and impolite staff. Users will always be encouraged to make use of the library where the quality of services rendered to them will help to satisfy their requests. The study also revealed that provision of relevant information materials, access point and conducive environment for learning, teaching and research lead to an increase in the use of library. Adeniran further affirm that "these findings confirm the earlier findings of Simmonds and Andaleeb (2001), Abagai (1993), Martensen and Gronholdt (2003), King (2005) and Hiller (2001) who observed in their findings that with qualified and experienced library staff, quality services are rendered to users who will always be encouraged to visit the library again". They concluded that if services rendered to users correspond with their needs, if users" needs are identified and satisfied and if easy access point to library resources is provided, if conducive environment is created for teaching and research activities, readers will be encouraged to visit and use the library resources frequently (Adeniran, 2011).

Osinulu (1998) confirmed in her study that low use of the library is due to lack of awareness on the part of the users. On the other hand, Ozoemelem (2009), stated that library users know that libraries have resources that are comprehensive and scholarly than what most web sites provide, but the problem is that these resources are not straightforward like that on the webs. Though users use the library for different purposes. Oyesiku and Oduwole (2004) in their study on the use of academic library revealed that students use the library mostly during examinations period. In a study conducted by Igun and Adogbeji (2007) they revealed that amongst the postgraduate students, majority of the students claimed that their major purpose of using the library is to update their knowledge and skills. It is therefore very essential to know the needs and opinions of the students in order to satisfy them. 
On the importance of the library resources, the study revealed that majority of the doctoral students, $78.6 \%$ of the respondents, who participated in the study indicated that their use of library resources was because of its importance to their research study. Also $61.2 \%$ of the respondents in the study reported that they found the library resources very dependable for their research study.

In the same study, 53.8\% of the respondents said they use the library's resources more for their research study. As regards the inquiry into the types of library resources used by doctoral students in the College of Humanities $86.7 \%$ respondents used electronic databases, while $78.6 \%$ used print materials (books and journals); and 61.2\% used dissertations and theses among other resources.

The study further justify the competence of the doctoral students in the College of Humanities in using the different library resources of the university library as 79 out of 99 respondents, representing $79.8 \%$ of the respondents considered themselves competent users of the different library resources with particular reference to electronic resources (Idoniboye-Obu, 2013).

\section{METHODOLOGY}

This study adopted a descriptive survey research design and the area of this study is Rivers State. The population of the study comprised all the 412 postgraduate students' registered with the Ignatius Ajuru University of Education Library, who are registered for the 2017/2018 academic session for postgraduate studies for the award of various degrees such as Postgraduate Diploma (PGD), MSc., MLS, PhD., etc. in different fields. Simple random sampling technique was used to sample fifty percent $(50 \%)$ of this population, which yield a sample of 206 postgraduate students registered with the Ignatius Ajuru University of Education Library. The instrument was a structured questionnaire titled Quality Library Information Resources and Postgraduate Students' Satisfaction in Ignatius Ajuru University of Education Library Questionnaire (QLIRPSSIAUE). The questionnaire was made-up of two (2) sections. Section A is about the personal data of respondents where the requirements were simply to fill as appropriate. Section B contained items which helped to provide information related to quality of information resources and postgraduate students' satisfaction with the use of Ignatius Ajuru University of Education Library. To ascertain the validity of the research instrument, the research supervisor, four experts in librarianship and others in the Department of Library and Information Science of Ignatius Ajuru University of Education assisted in reviewing the instrument and in order to ascertain the reliability, the instrument was trial tested by administering it to fifty (50) undergraduate students in Ignatius Ajuru University of Education (IAUE) who are not part of the study but similar to the respondents in the study, a reliability index of 0.70 guaranteed the usage of the instrument. The Data collected was analyzed using simple percentage, mean and standard deviation while regression model was used to test the hypotheses. 


\section{RESULT AND FINDINGS}

Table 1: Socio-Demographic Characteristics of Respondents

\begin{tabular}{llc} 
Socio-demographic Characteristics & Frequency $(\mathbf{F})$ & Percentage \% \\
\hline Gender & & \\
Male & 89 & 43.2 \\
Female & 117 & 56.8 \\
Total & $\mathbf{2 0 6}$ & $\mathbf{1 0 0 . 0}$ \\
& & \\
Programe & & \\
PGD & 56 & 27.2 \\
M.Sc./M.Ed. & 98 & 47.6 \\
PHD & 52 & 25.2 \\
Total & $\mathbf{2 0 6}$ & $\mathbf{1 0 0 . 0}$
\end{tabular}

Source: Field Survey, 2021.

Table 1 shows the gender distribution of the respondents. The male students represent frequency and percentage of $89(43.2 \%)$ while the females represent $17(56.8 \%)$. Based on programme of the students, 56(27.2\%) were PGD students, 98(47.6\%) were M.Sc./M.Ed. students, and 52(25.2\%), were Ph.D. students.

Research Questions 1: What is the relationship between print information resources and postgraduate students' satisfaction in Ignatius Ajuru University of Education library?

Hypothesis 1: There is no significant relationship between print information resources and postgraduate students' satisfaction in Ignatius Ajuru University of Education library.

Table 2: Relationship between print information resources and postgraduate students' satisfaction in Ignatius Ajuru University of Education library

\begin{tabular}{llccc}
\hline & \multicolumn{2}{c}{$\begin{array}{c}\text { Correlations } \\
\text { Print } \\
\text { Information } \\
\text { Resources }\end{array}$} & $\begin{array}{c}\text { Students' } \\
\text { Satisfaction }\end{array}$ & Decision \\
\hline Print Information & Pearson Correlation & 1 & .762 & Rejected \\
Resources & Sig. (2-tailed) & N & .000 & \\
Students' & Pearson Correlation & .762 & 206 & \\
Satisfaction & Sig. (2-tailed) & .000 & 1 & \\
& $\mathrm{~N}$ & 206 & 206 & \\
\hline
\end{tabular}

$* \mathrm{~S}=$ Significant $\mathbf{p}<0.05$

The result from SPSS analysis, shows the relationship between print information resources and postgraduate students' satisfaction in Ignatius Ajuru University of Education library. Pearson correlation coefficient demonstrates a strong positive relationship between the two variables 
$\mathrm{r}=.762$, indicating that there exists a strong positive relationship between print information resources and postgraduate students' satisfaction in Ignatius Ajuru University of Education library. Furthermore, the null hypothesis which states that there is no significant relationship print information resources and postgraduate students' satisfaction in Ignatius Ajuru University of Education library was rejected and the alternate hypothesis upheld $[(\mathrm{P}=.000) \mathrm{p}<0.05]$.

Research Questions 2: What is the relationship between electronic information resources and postgraduate students' satisfaction in Ignatius Ajuru University of Education library?

Hypothesis 2: There is no significant relationship between electronic information resources and postgraduate students' satisfaction in Ignatius Ajuru University of Education library

Table 3: Relationship between electronic information resources and postgraduate students' satisfaction in Ignatius Ajuru University of Education library

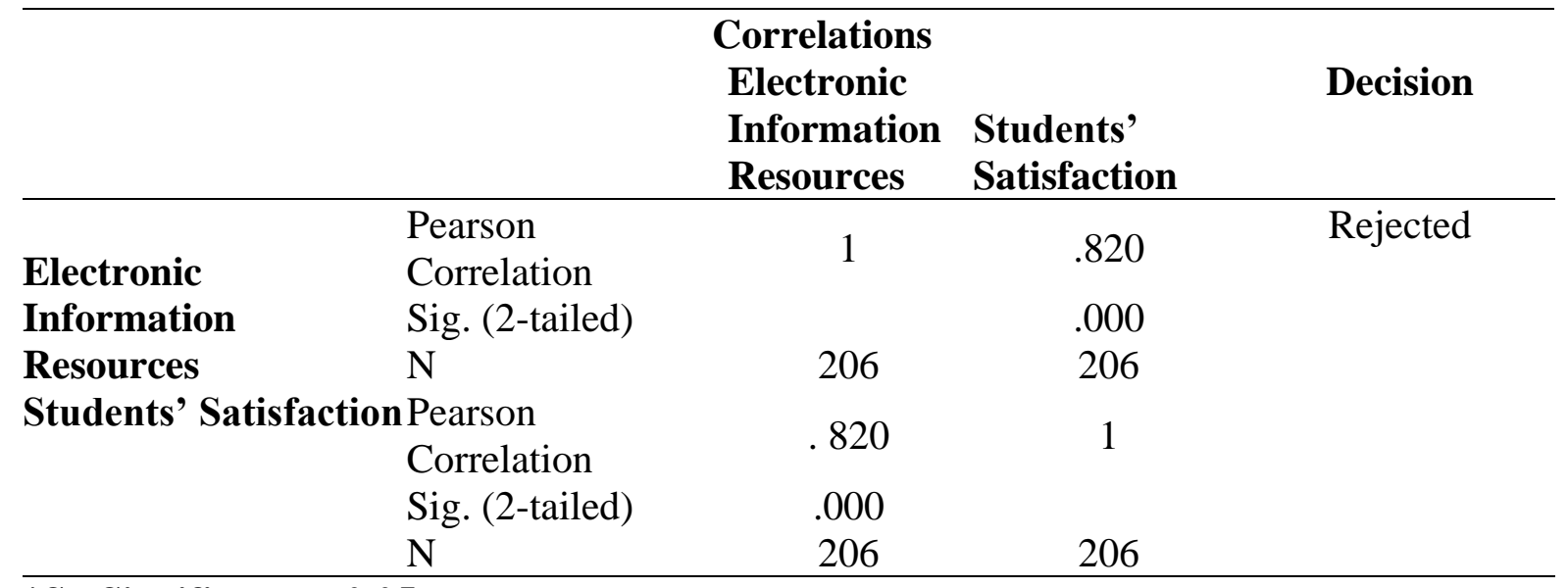

$* \mathrm{~S}=$ Significant $\mathbf{p}<0.05$

The result from SPSS analysis, shows the relationship between electronic information resources and postgraduate students' satisfaction in Ignatius Ajuru University of Education library. Pearson correlation coefficient demonstrates a strong positive relationship between the two variables $\mathrm{r}=.820$, indicating that there exists a strong positive relationship between electronic information resources and postgraduate students' satisfaction in Ignatius Ajuru University of Education library. Furthermore, the null hypothesis which states that there is no significant relationship between electronic information resources and postgraduate students' satisfaction in Ignatius Ajuru University of Education library was rejected and the alternate hypothesis upheld $[(\mathrm{P}=.000) \mathrm{p}<0.05]$.

\section{CONCLUSION}

The research looked at the consistency of information resources and the satisfaction of postgraduate students with the library at Ignatius Ajuru University of Education. The research discovered that knowledge tools such as textbooks and journals with uncompromising standards such as current and up-to-date, important to the fields of study, of good quality, credible, accessible, and accurate are available in the Ignatius Ajuru University of Education 
library. The information resources are accurate to library users' needs, satisfy the needs of postgraduate students, and the languages used in the information resources are very specific, resulting in postgraduate students' satisfaction when consulting the materials. One of the major factor inhibiting users' satisfaction in the Ignatius Ajuru University of Education library is a lack of understanding, among other aspects. This means that people would be able to use the library as long as the content of material resources and library facilities provided to them meet their demands and desires.

\section{RECOMMENDATIONS}

Based on the findings of the study, the following recommendations were made:

1. Relevant information resources to the library users' field, accessibility, adequacy, clarity of language of presentation, authenticity of information resources regular power supply, adequate computers/internet facilities should be considered and made available for the library users.

2. Awareness services should be done on regular basis in order to increase users' knowledge on library usage in order to guarantee users' satisfaction of Ignatius Ajuru University of Education library.

\section{REFERENCES}

Abiddin, N. Z., \& Ismail, A. (2011). Attrition and completion issues in postgraduate studies for student development. International Review of Social Sciences and Humanities, 1(2), $15-29$.

Adeleke, A. A. (2005). Use of library resources by academic staff of the Nigerian polytechnics. Journal of Library Science, 12(2), 15-24.

Adeniran, P. (2011). User satisfaction with academic libraries services: Academic staff and students perspectives. International Journal of Library and Information Science, 3(10), 209-216.

Adeoye, M. O., \& Popoola, S. O. (2011). Teaching effectiveness, availability, accessibility and use of library and information resources among teaching staff of schools of nursing in Osun and Oyo State, Nigeria. Library Philosophy and Practices, 3(1), 84-89.

Akande, O. (2003). Patterns of first-year students use of a university library: A Survey of University of Ibadan. Journal of Library and Information Science, 2(1), 22-26.

Akinade, O. J. (2000). Nigerian medical libraries challenge for the 21st century. Nigerian Libraries, 34(1), 46-54.

Akpojotor, O. (2016). "Awareness and usage of electronic information resources among postgraduate students of library and information science in southern Nigeria". Library Philosophy and Practice. 2(2), 1-11.

Andaleeb, S. S., \& Simmonds, P. L. (1998). Explaining user satisfaction with academic libraries: strategic implications. College and Research Libraries, 59(2), 156-167.

Anwar, M. A., \& Asghar, M. (2016). Information seeking behavior of Pakistani newspaper journalists. Pakistan Journal of Information Management and Libraries, 34(5), 757771. 
Bala, K. M., Abubakar, S. K., \& Usman, A. P. (2013). Influence of quality of information resources on tertiary students' satisfaction in academic libraries in Niger State, Nigeria. International Journal of Digital Library Science, 34(5), 757-771.

Barry, C. L. (1994). User-defined relevance criteria: An exploratory study. Journal of the American Society for Information Science, 45(3), 149-159.

Bates, J. (2010). "Information." Encyclopedia of library and information sciences. CRC Press.

Berg, C. (2017). "Teaching website evaluation, the CRAAN test and the evolution of an approach". International Journal of Digital Library Science, 34(5), 757-771.

Bitagi, A. M., \& Udoudoh, S. J. (2013). Library and information resources for effective scientific research in Nigerian universities. Proceedings of the International Conference of the School of Technology Education, 1, 171-175.

Blakeslee, S. (2004). Need for information literacy skills. Library and Information Science Academic Journal, 5(13), 34-39.

Campbell, J. D. (2006). Changing a Cultural Icon: the academic library as a virtual destination. Educause Review, 41(1), 16-18.

Chimah, J. T., \& Nwokocha, U. (2013). Information resources, retrieval and utilization for effective research in tertiary and research institutions. Asian Journal of Humanities and Social Sciences, 1(3), 20-21.

Cool, C., Belkin, N.J., Frieder, O., \& Kantor, P. (1993). Characteristics of texts affecting relevance judgments. Proceedings of the National Online Meeting, 14, 77-83.

Cooper, W. S. (1973). On selecting a measure of retrieval effectiveness. Journal of the American Society for Information Science, 24(2), 87-100.

Idoniboye-Obu, T. I. (2013). The use of library resources by doctoral students of the University of KwaZulu-Natal, College of Humanities, Pietermaritzburg campus. (Unpublished Ph.D. Dissertation), University of KwaZulu-Natal, Pietermaritzburg.

Nnadozie, C. O., \& Nwosu, C. C. (2016). Analysis of final year students' satisfaction with information resources and services in four Nigerian Federal University Libraries. International Journal of Advanced Library and Information Science, 4(2), 333-345.

Nworgu, B. G. (2006). Educational research: Basic issues and methodology. University Trust.

Olaisen, J. (1990). Information quality factors and the cognitive authority of electronic information. Definitions and dimensions. Taylor Graham.

Olajide, O., \& Adio, G. (2017). Effective utilisation of university library resources by undergraduate students: a case study of Federal University Oye-Ekiti, Nigeria. Library Philosophy and Practice, 19(21), 30-32.

Oliver, R. L. (1980). A cognitive model of the antecedents and consequences of satisfaction decisions. Journal of Marketing Research, 17, 460-469.

Park, T. K. (1993). The nature of relevance in information retrieval: An empirical study. Library Quarterly, 63(3), 318-351.

Popoola, S. O. (2008). The use of information sources and services and its effect on the research output of social scientists in Nigerian universities. Library Philosophy and Practice, 9(1), 23-25.

Popoola, S. O., \& Haliso, Y. (2009). Use of library information resources and services as predator of teaching effectiveness of social scientists in Nigerian universities. African Journal of Library, Archives and Information Science, 19(1), 65-77. 
Prangya, D., \& Rabindra, K. (2013). Access, awareness and use of electronic information resources by research scholars of Berhampur University: A study. American International Journal of Research in Humanities, Arts and Social Sciences, 3(2), 43-47.

Rasul, A., \& Singh, D. (2017). The role of academic libraries in facilitating postgraduate students' research. Malaysian Journal of Library and Information Science, 15(3), 7584.

Rieh, S. Y., \& Belkin, N. J. (1998). Understanding judgment of information quality and cognitive authority in the WWW. Proceedings of the Annual Meeting of the American Society for Information Science, 35, 279-289.

Uhegbu, A. N. (2009). Research and statistical method in library and information science. Barloz Publishers Incorporated.

White, M. D., \& Wang, P. (1997). A qualitative study of citing behavior: Contributions, criteria, and metalevel document concerns. Library Quarterly, 67(2), 122-154.

Wichowski, D., \& Kohl, L. (2013) "Establishing credibility in the information jungle: Blogs, microblogs, and the CRAAP Test". Library Staff Publications, Presentations and Journal, 2(12), 23-36.

Wilson, T, D. (2000). Human information behaviour. Information Science Research, 2(2), $25-$ 28. 